\title{
Tingkat Wanprestasi 90 Peer to Peer Lending Selama Pandemi COVID- 19 di Indonesia
}

\author{
Risna Kartika1, Mochamad Febri Sayidil Umam² \\ ${ }^{1}$ Universitas Galuh, ${ }^{2}$ Universitas Majalengka \\ email: 1risnakartika@gmail.com,2mochamad_febri@unma.ac.id
}

\section{Kata kunci: \\ COVID-19 \\ TWP 90 \\ Peer to Peer Lending \\ Indonesia}

\section{Keywords: \\ COVID-19 \\ TWP 90 \\ Peer to Peer Lending \\ Indonesia}

Risna Kartika dan Mochamad Febri Sayidil Umam (2021). Tingkat Wanprestasi 90 Peer to Peer Lending Selama Pandemi COVID-19 di Indonesia. Akuntabilitas : Jurnal Ilmiah Ilmu-Ilmu Ekonomi.31-39

\begin{abstract}
ABSTRAK
Fenomoena dalam penelitian ini terkait dengan adanya pandemi yang mulai dihadapi Indonesia sejak Maret 2020 yang membuat terpuruk berbagai sektor, selain kesehatan, ekonomi merupakan sektor yang juga terpukul oleh pandemi ini dengan kontraksi ekonomi di tahun 2020 sebesar 2,07\% dibandingkan tahun sebelumnya. Selama pandemi COVID-19 diketahui penyaluran kredit P2PL di Indonesia sangat fluktuatif. Penelitian ini bertujuan untuk mengetahui perbandingan antara TWP90 P2PL sebelum dan saat terjadi pandemi. Penelitian ini menggunakan metode deskriptif kuantitatif serta paired sample $t$ test. Penelitian ini memiliki hasil yaitu TWP90 P2PL sebelum dan saat terjadi pandemi berbeda secara signifikan. Kontribusi dalam penelitian ini dapat memberikan informasi bahwa meskipun dengan adanya pandemi COVID-19, peer to peer lending masih tetap bertahan dan unggul dalam industri IKNB, presentase TWP90 yang memang naik namun tetap didominasi oleh TKB90, sehingga masyarakat tetap dapat berinvestasi dan menggunakan platform ini dengan aman, nyaman dan memberikan prospek yang baik.
\end{abstract}

\section{ABSTRACT}

The phenomenon in this research is relate to the pandemic that began entered to Indonesia in March 2020 which has an impact on various sectors, beside health sector, economics is one of the most affected sectors with contraction of $2.07 \%$ in 2020 compared to the previous year. During the pandemic, it was noted that peer to peer credit distribution in Indonesia is fluctuating. This study has an aim to determine comparison between TWP90 P2PL before and during the pandemic. This study used descriptive quantitative with paired sample t test. This study has result, TWP90 P2PL before and during the pandemic is significantly different. The research contribution is can provide information that even at the pandemic, P2PL still survived and excelled in the IKNB industry, the percentage of TWP90 which increase but still dominated by TKB90, so that people could still invest and use this platform safely, comfortably and provide good prospects.

\footnotetext{
Tingkat Wanprestasi 90 Peer to Peer Lending Selama Pandemi COVID-19 di Indonesia 


\section{PENDAHULUAN}

Wuhan Municipal Health Commission di China melaporkan adanya sekumpulan kasus Pneumonia pada 31 Desember 2019 dan hal tersebut menjadi awal mula teridentifikasinya varian virus yang belum pernah ditemukan sebelumnya yakni Coronavirus Disease 2019 atau lebih populer disingkat menjadi COVID-19. Persoalan yang sama terjadi di Asia Tenggara termasuk yang pertama terjadi diluar China ialah di Thailand. Semakin meluas dan meningkatnya jumlah penyebaran berbanding lurus dengan bertambahnya tingkat kematian, sehingga kemudian WHO telah mengumumkan dan menetapkan virus ini sebagai pandemi karena telah menyebar dan melanda berbagai negara di dunia (WHO Timeline COVID-19, 2020).

Salah satu negara di Asia yang juga sedang mengalami badai pandemi ini ialah negara kita, Indonesia, sejak 2 Maret 2020 telah ditemukannya pasien pertama yang dinyatakan menderita COVID-19 dan sejak saat itu kasus-kasus baru mulai bermunculan di berbagai daerah di Indonesia (Almuttaqi, 2020). Penyebarannya yang masif menjadikan pandemi COVID-19 sebagai bencana nasional (Yuharnita, 2021). Sampai pada 9 April 2021 tercatat 1.558.145 orang terkonfirmasi positif, 1.405.659 dinyatakan sembuh dan 42.348 meninggal dunia (Data Sebaran Gugus Tugas COVID-19, 2021). Pandemi COVID-19 ini telah mengganggu stabilitas ekonomi dunia, berbagai negara terpukul dengan adanya pandemi yang tiba-tiba menghantam berbagai sektor, begitupun yang di rasakan Indonesia (Bidari, A; Simangunsong, F; Siska, 2020). Berbagai kebijakan telah ditetapkan oleh pemerintah untuk menekan bahkan memutus angka penyebaran terinfeksi COVID-19 (Kurniawan et al., 2020). Kebijakan yang diambil pemerintah ialah jalur kebijakan dua arah, yaitu kebijakan substansif (pencegahan) sembari melakukan perbaikan pada sisi ekonomi (Budi \& Anshari pada Kurniawan et al., 2020). Tak bisa dipungkiri COVID-19 mengakibatkan adanya krisis secara simultan sehingga banyak pihak yang terdampak (Eddoyono dalam Kurniawan et al., 2020). Kerugian dialami oleh hampir seluruh lapisan masyarakat, yang terbagi menjadi kerugian individu, perusahaan atau corporate, sektoral bahkan nasional (Hadiwardoyo, 2020).

Ekonomi dan keuangan merupakan sektor dan subsektor yang merasakan buruknya efek pandemi, karena nyata adanya pandemi ini mengganggu kinerja 
perusahaan baik skala besar maupun mikro kecil, di kota maupun di pedesaan (Bidari, A; Simangunsong, F; Siska, 2020; Yuharnita, 2021). Financial technology termasuk dalam sektor keuangan. Financial technology yang kemudian disingkat menjadi fintech (Wulandari, 2018) merupakan inovasi teknologi dalam layanan transaksi keuangan (Narastri \& Kafabih, 2020; Romadhona et al., 2019). Terdapat banyak jenis dari fintech, diantaranya yaitu peer to peer lending (P2PL) dan P2PL ini menjadi platform yang paling mendominasi, sehingga itu P2PL menjadi yang paling unggul dibidangnya (Risna Kartika, 2020), karena fintech diangggap sebagai alternatif pembiayaan khsususnya bagi usaha mikro kecil menengah (Putri Rusadi \& Benuf, 2020; Romadhona et al., 2019). POJK No 77/POJK.01/2016 berisi peraturan penyelenggaraan fasilitas kredit berdasarkan TI yang dirancang oleh OJK yang juga merupakan upaya pemerintah dalam mengatur mengenai pemberian ijin khususnya bagi yang menyelenggarakan layanan jasa keuangan dengan tujuan mengadakan transaksi atau kegiatan pinjam meminjam uang dengan menggunakan platform P2PL. Jumlah P2PL yang dinyatakan listed pada OJK sampai dengan bulan Februari tahun 2021 diketahui sebanyak 148. Pada bulan Februari tahun 2020 sebelum pandemi, P2PL yang terdaftar pada OJK diketahui lebih banyak yaitu 161 penyelenggara (Statistik Fintech, 2021). Sedangkan untuk total penyaluran kredit peer to peer lending setelah pandemi COVID-19 terjadi disajikan dalam Tabel 1.

Tabel 1. Total Penyaluran Kredit Perkembangan P2PL di Indonesia

\begin{tabular}{cccc}
\hline Tahun & Bulan & Total Kredit & Perubahan \\
\hline \multirow{2}{2020}{} & Maret & $\operatorname{Rp~102.534.393.511.190~}$ & - \\
\cline { 2 - 4 } & April & $\operatorname{Rp~106.059.242.151.486~}$ & $3 \%$ \\
\cline { 2 - 4 } & Mei & $\operatorname{Rp~109.175.311.472.646~}$ & $3 \%$ \\
\cline { 2 - 4 } & Juni & $\operatorname{Rp~113.460.536.674.324~}$ & $4 \%$ \\
\cline { 2 - 4 } & Juli & $\operatorname{Rp~116.970.933.056.942~}$ & $3 \%$ \\
\cline { 2 - 4 } & Agustus & $\operatorname{Rp~121.871.105.728.785~}$ & $4 \%$ \\
\cline { 2 - 4 } & September & $\operatorname{Rp~128.698.493.167.175~}$ & $6 \%$ \\
\cline { 2 - 4 } & Oktober & $\operatorname{Rp~137.656.286.533.943~}$ & $7 \%$ \\
\cline { 2 - 4 } & Nopember & $\operatorname{Rp~146.250.790.137.904~}$ & $6 \%$ \\
\cline { 2 - 4 } 2021 & Desember & $\operatorname{Rp~155.902.554.218.280~}$ & $7 \%$ \\
\cline { 2 - 4 } & Januari & $\operatorname{Rp~159.569.068.173.739~}$ & $2 \%$ \\
\hline
\end{tabular}

Sumber: Statistik Fintech (2021) 
Pada Tabel 1 dapat dilihat bahwa data total penyaluran kredit pada platform peer to peer lending berfluktuatif. Meskipun memperlihatkan kenaikan pada akhir tahun 2020 terjadi penurunan kembali pada awal tahun 2021. Tidak hanya itu, dampak COVID-19 menjadi semakin nyata, disisi lain kebijakan yang ditetapkan pemerintah bertujuan untuk mengurangi peningkatan kasus terkonfirmasi positif COVID-19 yang kemudian di berlakukan pada berbagai daerah, namun disisi lain kegiatan masyarakat khususnya perekonomian menjadi terbatas (Yuharnita, 2021). Hal ini tentu meningkatkan terjadinya resiko gagal bayar karena masyarakat atau pihak borrower mengalami kesulitan dalam memenuhi kewajibannya (Yuharnita, 2021). Pada penyelenggaraanya, terdapat risiko yang mungkin terjadi, diantanya ialah gagal bayar yaitu keadaan dimana debitur tidak mampu memenuhi kewajibannya sesuai dengan kesepakatan sebelumnya yang mengakibatkan piutang tersebut tidak dapat dipenuhi pembayarannya atau dengan kata lain disebut dengan Non Performing Loan (NPL), istilah NPL dalam peer to peer lending disebut dengan tingkat wanprestasi 90 (TWP90) yang memberikan informasi mengenai jumlah atau tingkat keterlambatan penyelesaian hutang atau kewajiban diatas 90 hari sejak jatuh tempo (Yuharnita, 2021). Penelitian lain yang telah dilakukan terkait dengan COVID19 dan financial technology antara lain pada bidang kesehatan tentang anosmia pada COVID-19 (Klopfenstein et al., 2020), penelitian lain yaitu dampak pandemi pada berbagai sektor yaitu sektor ekonomi di Indonesia (Nasution et al., 2020), dampak pandemi pada UMKM (Thaha, 2020), dampak pandemi pada bidang pendidikan yaitu pembelajaran (Mansyur, 2020; Pratiwi, 2020), sampai dengan kebijakan menangani pandemi COVID-19 (Kurniawan et al., 2020) termasuk kebijakan PSBB dalam rangka menangani penyebaran COVID-19 di Indonesia (Thorik, 2020). Mengenai konsep dan implementasi fintech di Indonesia (Nizar, 2017). Penelitian lain yang meneliti mengenai P2PL diantaranya ialah membahas mengenai perlindungan dan keamanan konsumen pengguna P2PL (Hidayat et al., 2020), penelitian yang mengkaji regulasi yang mengatur mengenai P2PL (Wulandari, 2018), selanjutnya telah dilakukan penelitian tentang solusi pembiayaan operasional usaha mikro kecil menengah dengan menjadikan P2PL sebagai alternatif pembiayaan yang mudah dan cepat dalam berbagai aspek (Putri Rusadi \& Benuf, 2020), penelitian mengenai 
UMKM di Indonesia yang dapat ditingkatkan salah satunya dengan fasilitas peer to peer lending (Romadhona et al., 2019), penelitian lainnya membahas mengenai peer to peer lending Syariah (Baihaqi, 2018; Tsuroyya, 2019), yang kemudian menjadi pembeda dalam penelitian ini yakni penelitian ini menggunakan variabel TWP90 P2PL dengan kondisi sebelum dan setelah adanya pandemi.

\section{METODE PENELITIAN}

Penelitian ini menggunakan deskriptif kuantitatif, serta menggunakan data sekunder yang diakses dari Statistik Finceh Otoritas Jasa Keuangan (OJK) dengan menggunakan data Tingkat Wanprestasi 90 atau TWP 90, dimulai pada bulan Maret 2019 sampai dengan Februari 2021 bagi perusahaan P2PL yang tercatat pada OJK, sampai dengan Februari 2021 diketahui ialah sebanyak 148 perusahaan (Statistik Fintech, 2021).

\section{Perhitungan:}

TWP90 $=($ Outstanding Wanprestasi diatas 90hari) $/($ Total Outstanding) $\times 100 \%$ (Sumber: POJK No. 77/POJK.01/2016)

TWP90 sendiri ialah singkatan dari Tingkat Wanprestasi dapat diartikan sebagai penyelesaian kewajiban yang lalai dilakukan oleh debitur terkait dengan pembayaran yang dilakukan diatas 90 hari sejak adanya tanggal jatuh tempo sesuai dengan yang telah disepakati sebelumnya. Paired sample $t$ test dilaksanakan guna mendapati perbedaan rata-rata untuk dua sampel yang masing-masing berpasangan, berpasangan disini maksudnya ialah subjek tersebut ialah sama tetapi memperoleh perlakuan yang berbeda, salah satu contohnya ialah perlakuan sebelum dan sesudah (Priyatno, 2012).

Hipotesis dalam penelitian ini ialah :

Ho : $\quad$ Tidak terdapat perbedaan Tingkat Wanprestasi 90 peer to peer lending sebelum dan pada saat pandemic covid19 di Indonesia.

Ha : Terdapat perbedaan Tingkat Wanprestasi 90 peer to peer lending sebelum dan pada saat pandemic covid19 di Indonesia. 


\section{PEMBAHASAN}

Banyak jenis fintech yang beroperasi di Indonesia, namun P2PL termasuk yang paling banyak digunakan serta menajadi unggulan (Kartika, 2020). Menurut Statistic Fintech tahun 2021, sampai dengan bulan Februari terdapat 148 yang menyelenggarakan P2PL, 3 diantaranya ialah syariah berizin, 7 syariah terdaftar, 96 konvensional terdaftar dan 42 konvensional berizin. Untuk data TWP90 peer to peer lending sebelum terjadinya pandemi COVID19 cukup fluktuatif, namun selama pandemi COVID-19 TWP90 untuk P2PL fluktuatif cenderung naik, data ditampilkan dalam Gambar 1.

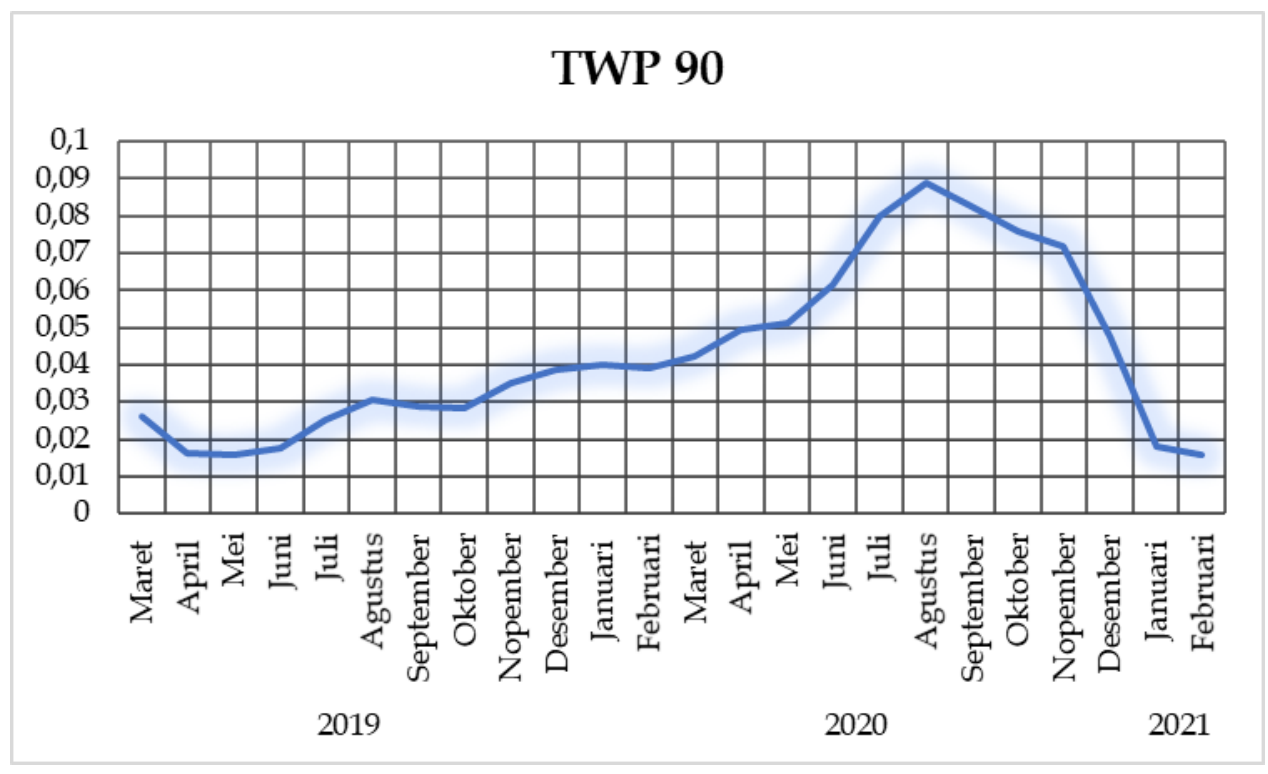

\section{Gambar 1. \\ Tingkat Wanprestasi 90 Hari Peer to Peer Lending Sumber: Statistic Fintech (2021)}

Berdasarkan tabel 1.2 sebelum pandemi COVID-19 dari Maret 2019 sampai dengan Februari 2020 rata-rata TWP90 peer to peer lending hanya sebesar 2,85\%, dengan TWP90 paling tinggi pada Januari 2020 yaitu sebesar 3,98\% dan TWP90 paling kecil pada Juni 2019 yaitu 1,57\%. Sedangkan setelah pandemi COVID-19 dari bulan Maret 2020 sampai dengan bulan Februari 2021 rata-rata TWP90 P2PL sebesar 5,70\% dengan TWP90 tertinggi terjadi pada bulan Agustus 2020 sebesar 8,88\% sedangkan TWP90 terendah 1,59\% yang terjadi pada bulan Februari 2021. Dengan demikian, untuk menguji perbedaan tersebut berarti atau tidak dan untuk mengetahui perbedaan TWP90 maka dipenuhi Paired Sample $t$ test. Menurut Paired Sample $t$ test, terkandung perbedaan Tingkat Wanprestasi 90 P2PL sebelum dan 
selama terjadi pandemi COVID-19 di Indonesia. Selama pandemi terjadi, TWP P2PL memiliki kecenderungan lebih tinggi daripada sebelum pandemi. Hal ini dapat terlihat juga dari akumulasi penyaluran pinjaman yang cenderung menurun setelah pandemi, rata-rata pertumbuhan penyaluran pinjaman sebelum pandemi COVID-19 dari Maret 2019 sampai dengan Februari 2020 ialah 10,08\% namun setelah pandemi COVID-19 yaitu dari Maret 2020 sampai dengan Februari 2021 pertumbuhan penyaluran kredit menjadi 4,69\%.

Dampak pandemi COVID-19 pada ekonomi sangat besar, khususnya di Indonesia (Satradinata \& Muljono, 2020). Sejalan dengan itu, dibandingkan dengan sebelum adanya pandemi ini, telah terjadi penurunan pertumbuhan ekonomi sebesar 2,07\% pada tahun 2020 (Badan Pusat Statistik, 2021). Setelah terjadi pandemi COVID19, pemerintah telah mengatur dan mengelola kebijakan demi menjaga agar perkonomiann tetap stabil melalui OJK yang disebut dengan kebijakan countercyclical (Asyhadi, 2020), P2PL termasuk dalam IKNB yang terkena buruknya efek pandemi selanjutnya diatur dalam POJK No. 14/POJK.05/2020 yang kemudian terdapat perubahan menjadi POJK No. 58/POJK.05/2020, kebijakan tersebut mengenai penetapan kualitas aset yang diantaranya merupakan restrukturisasi pembiayaan, penentuan batas wkatu penyampaian laporan rutin atau berkala, pelaksanaan kepatutan dan penilaian kemampuan, serta lainnya. Namun demikian memang belum ada peraturan khusus restrukturisasi pinjaman pada P2PL (Yuharnita, 2021). Kontribusi penelitian ini ialah meski pandemi COVID-19 berdampak pada seluruh lapisan masyarakat, tetapi untuk P2PL masih tetap bertahan dan tetap unggul di bidang Industri Keuangan Non Bank (IKNB), meski presentase TWP90 naik, namum pinjaman yang termasuk dalam kategori lancar atau disebut dengan Tingkat Keberhasilan 90 (TKB90) lebih dominan dengan rata-rata diatas 90\%, sehingga dirasa masih aman dan juga berprospek baik untuk menggunakan investasi dengan platform P2PL khususnya di Indonesia.

\section{KESIMPULAN}

Sejak tanggal 2 Maret tahun 2020 Indonesia dan berbagai negara di seluruh dunia tengah berjuang menghadapi badai pandemi yang sudah lebih dari 1 tahun ini 
melanda. Selain sektor kesehatan, ekonomi termasuk sektor yang terdampak pandemi ini, khususnya jenis P2PL yang termasuk dalam bidang financial technology. Setelah terjadinya pandemi COVID-19, pemerintah menerapkan berbagai macam kebijakan, diantaranya yaitu kebijakan dua arah, yakni kebijakan substansif sembari melakukan kebijakan pada sisi ekonomi, termasuk PSBB utnuk mengurangi tingkat penyebaran COVID-19, disisi lain kegiatan perekonomian menjadi terbatas. Dilihat dari penyaluran kredit peer to peer lending sejak Maret 2020 sampai dengan akhir tahun 2020 fluktuatif dan mulai mengalami kenaikan kembali pada Februari 2021. Sedangkan untuk kredit macet yang diwakili oleh TWP90 sebelum dan selama pandemi COVID-19 berdasarkan uji paired sample test diketahui memiliki perbedaan. Selama pandemi TWP90 cenderung lebih tinggi, meski demikian kategori kredit lancar masih mendominasi diatas 90\%, sehingga dapat dikatakan bahwa meskipun pandemi COVID-19 masih berlangsung, tetapi investasi menggunakan platform P2PL yang sudah tercatat, terdaftar serta sudah berizin dari OJK termasuk dalam investasi yang aman dan memiliki prospek yang baik untuk kedepannya.

\section{DAFTAR PUSTAKA}

\section{Jurnal}

Almuttaqi, A. I. (2020). The Chaotic Response To Covid-19 In Indonesia. The Habibie Center Insights, 1(13), 1-7. http://habibiecenter.or.id/img/publication/66f28c42de71fefe1c6fcdee37a5c1a6. pdf

Asyhadi, F. (2020). Analisis Dampak Restrukturisasi Kredit Terhadap Pembiayaan (Leasing) Pada Masa Pandemi Corona Virus Disease 2019. Justisi Jurnal Ilmu Hukum, 5(1), 43-53. https://doi.org/10.36805/jjih.v5i1.1269

Baihaqi, J. (2018). Financial Technology Peer-To-Peer Lending Berbasis Syariah Di Indonesia. TAWAZUN: Journal of Sharia Economic Law, 1(2), 116. https://doi.org/10.21043/tawazun.v1i2.4979

Bidari, A; Simangunsong, F; Siska, K. ; (2020). SEKTOR PERBANKAN di COVID-19. Jurnal Pro Hukum: Jurnal Penelitian Bidang Hukum Universitas Gresik, 9(1), 1-9.

Hadiwardoyo, W. (2020). Kerugian Ekonomi Nasional Akibat Pandemi Covid-19. Baskara: Journal of Business and Entrepreneurship, 2(2), 83-92. https:// doi.org/10.24853/baskara.2.2.83-92

Hidayat, A. S., Alam, F. S., \& Helmi, M. I. (2020). Consumer protection on peer to peer lending financial technology in Indonesia. International Journal of Scientific and Technology Research, 9(1), 4069-4072.

Klopfenstein, T., Kadiane-Oussou, N. J., Toko, L., Royer, P. Y., Lepiller, Q., Gendrin, V., \& Zayet, S. (2020). Features of anosmia in COVID-19. Medecine et Maladies 
Infectieuses, 50(5), 436-439. https:// doi.org/10.1016/j.medmal.2020.04.006

Kurniawan, H. H., Salahuddin, A. M., Muslim, \& Sri, N. (2020). KONSEP KEBIJAKAN STRATEGIS DALAM MENANGANI EKSTERNALITAS EKONOMI DARI COVID - 19 PADA MASYARAKAT RENTAN DI INDONESIA Heri. Indonesian Journal of Social Sciences and Humanities, 1(2), 130139. file:/ / / :/Users/User/Downloads/fvm939e.pdf

Mansyur, A. R. (2020). Dampak COVID-19 Terhadap Dinamika Pembelajaran Di Indonesia. Education and Learning Journal, 1(2), 113-123. https://doi.org/10.33096/eljour.v1i2.55

Narastri, M., \& Kafabih, A. (2020). Financial Technology (FINTECH) di IndonesiDitinjau dari Perspektif Islam. Indonesian Interdiciplinary Journal of Sharia Economics (IIJSE), 2(2), 31-48. https://doi.org/10.4324/9780429344015-2

Nasution, D. A. D., Erlina, E., \& Muda, I. (2020). Dampak Pandemi COVID-19 terhadap Perekonomian Indonesia. Jurnal Benefita, 5(2), 212. https://doi.org/10.22216/jbe.v5i2.5313

Nizar, M. A. (2017). Financial Technology ( Fintech ): It ' s Concept and Implementation in Indonesia. Munich Personal RePEc Archive, V(98486), 15.

Pratiwi, E. W. (2020). Dampak Covid-19 Terhadap Kegiatan Pembelajaran Online Di Perguruan Tinggi Kristen Di Indonesia. Perspektif Ilmu Pendidikan, 34(1), 1-8. https://doi.org/10.21009/pip.341.1

Putri Rusadi, F. A. R., \& Benuf, K. (2020). Fintech peer to peer lending as a financing alternative for the development MSMEs in Indonesia. Legality: Jurnal Ilmiah Hukum, 28(2), 232-244. https:/ / doi.org/10.22219/ljih.v28i2.12865

Risna Kartika. (2020). Analisis Peer To Peer Lending Di Indonesia. AKUNTABILITAS: Jurnal Ilmiah Ilmu-Ilmu Ekonomi, 12(2), 75-86. https://doi.org/10.35457/akuntabilitas.v12i2.902

Romadhona, S., Hamzah, M. Z., \& Sofilda, E. (2019). Fintech Peer-To-Peer Lending Sebagai Peluang Peningkatan Umk Di Indonesia. Media Ekonomi, 26(2), 121-126. https://doi.org/10.25105/me.v26i2.5219

Satradinata, D. N., \& Muljono, B. E. (2020). Analisis Hukum Relaksasi Kreadit Saat Pandemi Corona Dengan Kelonggaran Kredit Berdasarkan Peraturan Otoritas Jasa Keuangan Nomor 11/POJK.03/2020. Jurnal Sains Sosio Humaniora, 4(2), 613620. https://doi.org/10.22437/jssh.v4i2.11009

Thaha, A. F. (2020). Dampak Covid-19 Terhadap UMKM Di Indonesia [The Impact of Covid-19 on MSMEs in Indonesia]. Jurnal Brand, Universitas Maros, 2(1), 148-153.

Thorik, S. H. (2020). Efektivitas Pembatasan Sosial Berskala Besar Di Indonesia Dalam Penanggulangan Pandemi Covid-19. Jurnal Adalah: Buletin Hukum Dan Keadilan, 4(1), 115-120.

Tsuroyya, D. (2019). Analisis Pelaksanaan Musyarakah Pada Layanan Financial Technology Peer To Peer Lending Syariah Di Indonesia ( Study PT Syarfi Teknologi Finansial). Sustainability (Switzerland), 11(1), 1-14. http://scioteca.caf.com/bitstream/handle/123456789/1091/RED2017-Eng8ene.pdf?sequence=12\&isAllowed=y\%0Ahttp: / / dx.doi.org/10.1016/j.regsciurb eco.2008.06.005\%0Ahttps://www.researchgate.net/publication/305320484_SIST EM_PEMBETUNGAN_TERPUSAT_STRATEGI_MELESTARI

Wulandari, F. E. (2018). Peer To Peer Lending Dalam Pojk, Pbi Dan Fatwa Dsn Mui. Ahkam:

Jurnal

Hukum

Islam,

$6(2)$,

241-266.

Tingkat Wanprestasi 90 Peer to Peer Lending Selama Pandemi COVID-19 di Indonesia 
https:/ / doi.org/10.21274/ahkam.2018.6.2.241-266

Yuharnita, S. (2021). Kebijakan Restrukturisasi Pinjaman Pada Peer To Peer Lending. Media Iuris, 4(1), 91. https:/ / doi.org/10.20473/mi.v4i1.24832

\section{Buku}

Priyanto, Duwi. (2012). Cara Kilat Belajar Analisis Data dengan SPSS20. Yogyakarta: Penerbit ANDI.

\section{Internet}

Badan Pusat Statistik. (2021). Ekonomi Indonesia 2020 Turun sebesar 2,07 Persen (cto-c). $\quad$ https://www.bps.go.id/pressrelease/2021/02/05/1811/ekonomiindonesia-2020-turun-sebesar-2-07-persen--c-to-c-

.html\#: :text=Perekonomian\%20Indonesia\%202020\%20yang\%20diukur,\%2Dc) \%20dibandingkan\%20tahun\%202019.

Data Sebaran Gugus Tugas Percepatan Penanganan COVID-19. (2021). https://covid19.go.id/

Gugus Tugas Percepatan Penanganan COVID-19. (2020). Protokol Percepatan Penanganan Pandemi COVID-19 (Corona Virus Disease 2019). https://covid19.go.id/storage/app/media/Protokol/2020/Mei/Protokol\%20 Percepatan \%20Penanganan\%20Pandemi \%20Corona \%20Virus \%20Disease $\% 20$ 2019.pdf

Gugus Tugas Percepatan COVID-19. (2021) Setahun Pandemi: Perkembangan Grafik Menjadi Refleksi Kualitas Penanganan. https://covid19.go.id/p/berita/setahun-pandemi-perkembangan-grafikmenjadi-refleksi-kualitas-penanganan

Statistik Fintech. (2021). https://www.ojk.go.id/id/kanal/iknb/data-danstatistik/fintech/Default.aspx

WHO Timeline COVID-19. (2020). Archived: WHO Timeline - COVID-19. https://www.who.int/news/item/27-04-2020-who-timeline---covid-19 